\title{
Variability of Spartina alterniflora primary production in the euhaline North Inlet estuary
}

\author{
Richard F. Dame ${ }^{1,2} \&$ Paul D. Kenny ${ }^{2}$ \\ ${ }^{1}$ Coastal Carolina College, University of South Carolina, Conway, South Carolina 29526, USA \\ ${ }^{2}$ Belle W. Baruch Institute for Marine Biology and Coastal Research, Georgetown, South Carolina 29442, USA
}

\begin{abstract}
Monthly live and dead aboveground and belowground biomass and decomposition rates of Spartina alterniflora were observed spatially and temporally in the North Inlet euhaline marshestuarine system. All areas exhibited seasonal patterns, but Creekside live aboveground biomass varied significantly year-to-year. Creekside live biomass was higher during the years following depressed winter-spring salinities in North Inlet. Salinity depression in North Inlet appears to be correlated with increased rainfall. Net aboveground primary production averaged $2188 \mathrm{~g} \mathrm{~m}^{-2} \mathrm{yr}^{-1}$ for Creekside, $724 \mathrm{~g} \mathrm{~m}^{-2} \mathrm{yr}{ }^{1}$ for Midmarsh and $1295 \mathrm{~g} \mathrm{~m}^{-2} \mathrm{yr}^{-1}$ for Highmarsh. Net belowground primary production was $2363 \mathrm{~g} \mathrm{~m}^{-2} \mathrm{yr}^{-1}$ for Creekside and $5445 \mathrm{~g} \mathrm{~m}^{-2} \mathrm{yr}^{-1}$ for Highmarsh. Total production for $S$. alterniflora was the highest yet reported. Turnover rates ranged from 0.7 to $5.1 \mathrm{yr}^{-1}$, the highest value occurring in the aboveground Highmarsh
\end{abstract}

\section{INTRODUCTION}

Primary producers usually control the amount of energy and matter entering an ecosystem and thus form the basis of many food webs. An accurate measurement of primary production is thus essential to the understanding of ecosystem structure and function. In the marsh-estuarine ecosystems of the east coast of the United States, Spartina alterniflora Loisel. is often the dominant emergent vascular plant and varies in height from a tall $(1.5 \mathrm{~m})$ form at the creekbanks to a short $(0.5 \mathrm{~m})$ form high in the marsh near the uplands. Because of their high productivity and location in the rapidly developing coastal zone, Spartina marshes have been extensively studied (Keefe 1972, Turner 1976)

In vascular plants, total primary production is the sum of below- and aboveground production. Few studies (Schubauer \& Hopkinson 1984) have addressed aerial and belowground production of Spartina simultaneously. Because of the labor-intensive aspects of the harvest methods usually employed in emergent macrophyte production studies, statistical accuracy is usually low as sampling is limited to at best $1 \mathrm{yr}$ of monthly observations.

Differences in Spartina production exhibited by different height forms within a marsh and similar height forms in different systems are attributed to variations in soil water movement, tidal range, temperature, insolation, length of growing season, salinity, and nutrient availability (Turner 1976. Shew et al. 1981, Wiegert et al. 1983). As part of a larger ecosystem level study, it is the objective of this study to determine the net primary production of $S$. alterniflora both spatially and temporally in the extensively studied North Inlet, South Carolina marsh-estuarine ecosystem and to identify possible factors which cause year-to-year variability.

\section{DESCRIPTION OF AREA}

North Inlet near Georgetown, South Carolina (Fig. 1) is an extensively studied marsh-estuarine system covering $32 \mathrm{~km}^{2}$. Spartina alterniflora is the dominant emergent vascular plant in this system and grades from a tall form on the creek banks through a medium form to a short form near the uplands. At mean tide, $S$. alterniflora salt marsh covers $75.2 \%$ of the total area with the remaining area being creeks, oyster reefs and mud/sand flats. The system is ocean-dominated by semi-diurnal tides with a mean range of $1.4 \mathrm{~m}$ and maximum range of $2.4 \mathrm{~m}$. There is also an annual cycle of sea level rise and fall due to cycles in sea temperature and atmospheric pressure which result in the 


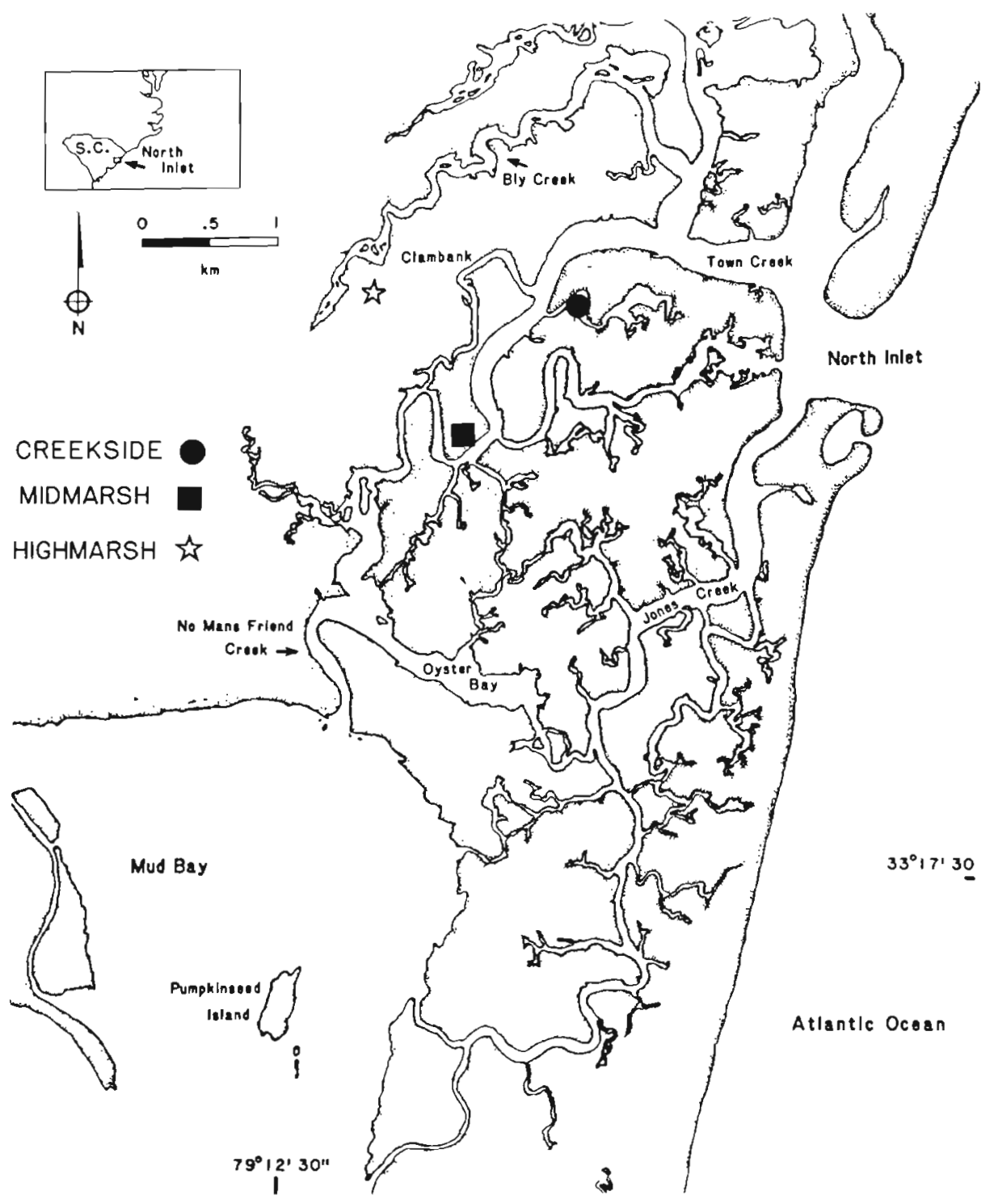

Fig. 1. Location of sample sites within the North Inlet marshestuarine system

marsh being covered by water $42 \%$ of the time in October compared to $27 \%$ of the time in January with an average coverage of $30 \%$ (Kjerfve et al. 1978). Salinity is near-oceanic, having a yearly-average salinity of $34.6 \mathrm{ppt}$. Fresh water input from groundwater, surface runoff and rainfall is generally low (Kerfve et al. 1982).

\section{METHODS}

Because of the spatial variation in height forms, 3 sites (Fig. 1) with near-homogeneous distributions of stands of tall, medium and short Spartina alterniflora were chosen for study. The Creekside site covered by tall $S$. alterniflora encompassed the edges of Bread and Butter Creek to a horizontal distance of $3 \mathrm{~m}$ from the Creek edge. The Midmarsh site covered by medium height $S$. alterniflora is located off Town Creek $(40 \mathrm{~m}$ $\times 100 \mathrm{~m}$ ) and the Highmarsh site covered by short $S$. alterniflora is located at the upper reaches of Bly Creek $(30 \mathrm{~m} \times 70 \mathrm{~m})$. The sites were sufficiently large to ensure no sample plot would be resampled over the duration of the study.

Aboveground methods. The harvest method of Shew et al. (1981) was used to determine net aboveground primary production (NAPP). In this method, it is assumed that (1) the study sites are homogenous with respect to plant distribution and height, (2) the removal of dead material has no effect on the mortality of live plants and (3) there is no loss of material from a site between samplings. The first assumption was justified by choosing sites based on uniformity of plant size, distribution and monospecificity. Initial experiments showed $1 / 4 \mathrm{~m}^{2}$ sample plots were equivalent to $1 / 2 \mathrm{~m}^{2}$ 
plots in determining live biomass estimates, thus the smaller size was used. These observations also indicated that 10 Creekside, 15 Midmarsh and 5 Highmarsh replicates provided mean estimates with less than $20 \%$ variability. Sites with sufficient area were selected so that $10 \%$ of the total site area would be cut in 5 yr of monthly sampling. The validity of the second assumption was verified by comparing growth data from plots containing dead material to plots in which dead material had been removed (Dame unpubl.). The final assumption was satisfied by utilizing $1.5 \mathrm{~m}$ tall screen cages ( $1 \mathrm{~mm}$ mesh) to minimize tidal influences and litter bags to estimate decomposition between samplings.

NAPP was determined monthly from June 1981 to October 1985 utilizing the methods of Shew et al. (1981) as follows: 2 replicates (A and B) were designated at the first visit. Plot $A$ was clear cut on the initial visit with all plant material and detritus removed. This material was later divided into live plant, dead plant parts, and other dead material. Dead material is defined subjectively as plant material which is less than $10 \%$ green. On the initial visit, Plot B was cleared of all standing dead plants and detritus, but not attached dead parts, then a screen cage open at the top was placed over Plot B. On the return visit about 1 mo later, the screen cage was removed and Plot B was clear cut with material divided into live and dead. All samples were refrigerated (not frozen) until sorted. The sorted samples were dried in an oven at $100^{\circ} \mathrm{C}$ for $48 \mathrm{~h}$ and weighed to the nearest $0.1 \mathrm{~g}$.

Beginning in September 1982, decomposition rates of leaves and shoots were estimated for 5 samples from each zone each month. Initial live material was washed, air dried for $48 \mathrm{~h}$, weighed, and subdivided into 2 portions. One portion was returned to the appropriate site in $1 \mathrm{~mm}$ mesh bags and the other portion was oven dried for $48 \mathrm{~h}$ at $100^{\circ} \mathrm{C}$ and weighed. After about $25 \mathrm{~d}$ the initial bagged portion was collected, washed and oven dried as before. The percent decomposition or disappearance was determined by dividing the difference between the initial and final weights by the initial weight and multiplying by 100 .

The calculated aboveground values were: change in live material $(\Delta L)$, mortality $(M)$, and net aerial primary production (NAPP). Change in live material was the difference in mean live standing crop at time $t_{1}$ and time $t_{2}$ for the same site. Mortality was estimated by subtracting the dead parts in Plot A from the dead material in the return Plot B over the monthly interval. Decomposition (D) was calculated by multiplying the dead biomass in each plot by the appropriate decomposition rate determined above. For the time before September 1982, average decomposition rates from observed months were utilized for the appropriate sites. The value for NAPP was the sum of $\triangle \mathrm{L}$, and $\mathrm{M}$, and D. To maintain statistical consistency, both positive and negative values for $\Delta \mathrm{L}, \mathrm{M}$ and $\mathrm{D}$ were utilized.

Belowground methods. Belowground biomass and production were estimated every other month from July 1983 to September 1984 for the Creekside and Highmarsh sites. Statistical analysis indicated 8 cores from Creekside and 12 cores from Highmarsh were necessary to obtain no more than $20 \%$ variability about the mean. Cores were taken within $10 \mathrm{~d}$ from plots harvested the previous month for aboveground productivity. The coring device was a plastic pipe $10.2 \mathrm{~cm}$ in diameter $\left(0.00817 \mathrm{~m}^{2}\right)$ and $40 \mathrm{~cm}$ long with the edge sharpened at one end. The core samples were washed, sieved (1 $\mathrm{mm}$ pore size), animals were removed, and live root/rhizome material was separated from dead material by color and texture (Valiela et al. 1976). The live and dead samples were dried separately at $100^{\circ} \mathrm{C}$ for $48 \mathrm{~h}$ and then weighed. Because of the large quantity of sand present in the dead Highmarsh samples, subsamples of this material were burned in a muffle furnace at $550^{\circ} \mathrm{C}$ for $6 \mathrm{~h}$ to estimate sediment content in order to correct the biomass measurements.

Yearly net belowground primary production (NBPP) was calculated by the Smalley (1959) method which considers change in live and dead material, without determining decomposition rates. Computation of NBPP per sampling interval was as follows: (1) if changes in both live and dead material are positive for a time interval, NBPP equals the sum of those changes; (2) if changes in both live and dead material are negative, then production is zero; (3) if live biomass decreased through the interval and dead material increased, and if their algebraic sum is positive, then NBPP equals that value, however if the algebraic sum is negative, NBPP is zero; and (4) if live material increased and dead material decreased through the interval, NBPP equals the live biomass value. The values for each time interval are summed to provide an estimate of annual NBPP (Shew et al. 1981).

\section{RESULTS AND DISCUSSION}

The amount of live aboveground material was highest at the Creekside site, varying from 75 to $1150 \mathrm{~g} \mathrm{~m}^{-2}$ (Fig. 2). Live aboveground biomass was lowest at the Midmarsh site ranging from 25 to $310 \mathrm{~g} \mathrm{~m}^{-2}$ (Fig. 2). The amount of live leaf and shoot biomass was intermediate in value at the Highmarsh site varying from 25 to $350 \mathrm{~g} \mathrm{~m}^{-2}$ (Fig. 2).

Spatial heterogeneity in aboveground density, height, and production has long been observed in Spartina alterniflora marshes. There is usually a gra- 

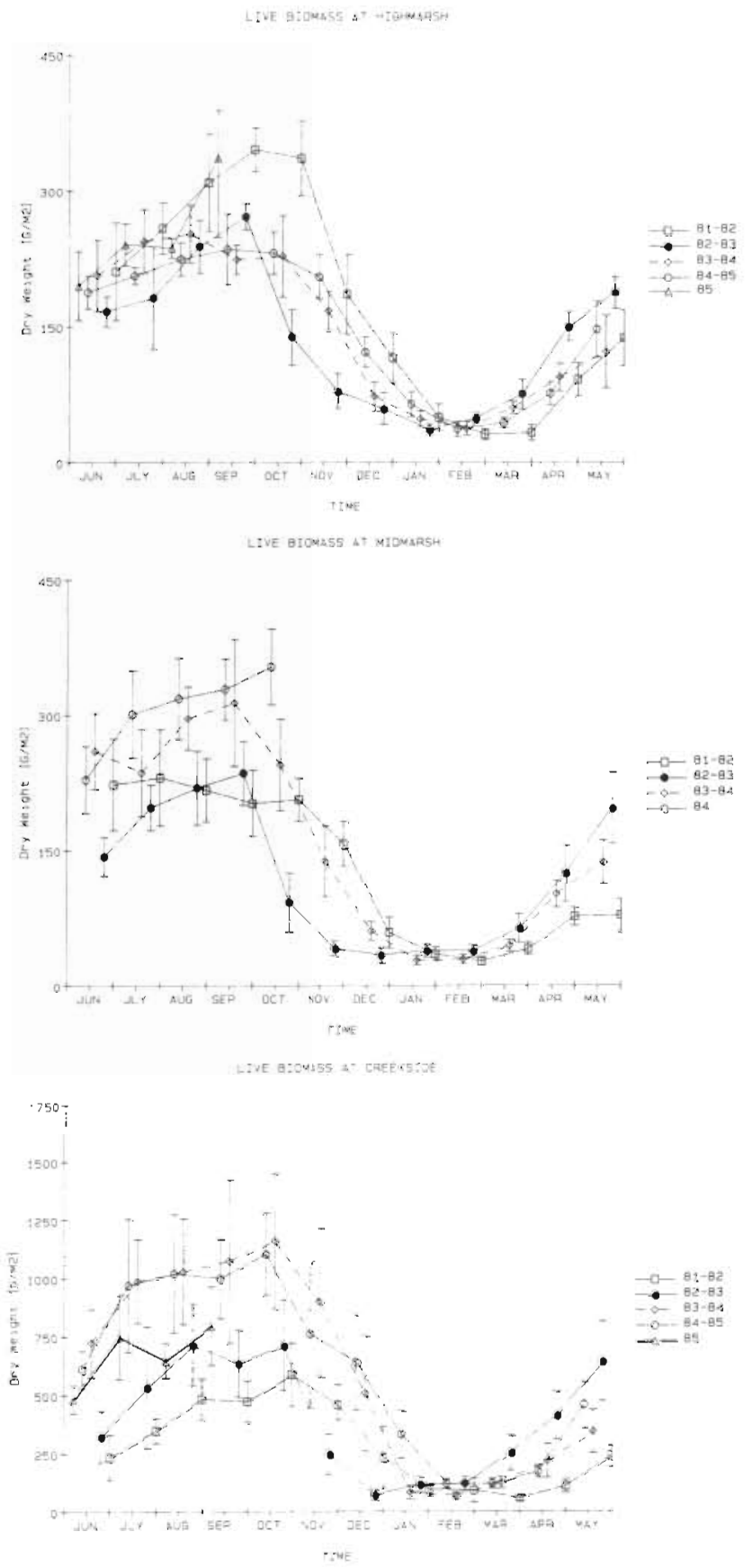

Fig. 2. Monthly aboveground live biomass at the Highmarsh, Midmarsh and Creekside sites. Vertical bars: $95 \% \mathrm{CI}$

dient in plant size from Creekside to Highmarsh, but in North Inlet, biomass $\mathrm{m}^{-2}$ is lower at the Midmarsh site. These low values at the Midmarsh site seem to be a function of an abundance of relatively light (weak) individuals with a low density distribution (Table 1). While we did observe a high-to-low gradient of stem height, no gradient was observed for productivity with very low NAPP in the Midmarsh and higher production in Creekside and Highmarsh. From our observations,
Table 1. Spartina alterniflora. Comparison of mean \pm standard error of stem weight, height and density in Creekside, Midmarsh and Highmarsh zones in North Inlet in August 1982

\begin{tabular}{|c|c|c|c|}
\hline Parameter & Creekside & $\begin{array}{c}\text { Zone } \\
\text { Midmarsh }\end{array}$ & Highmarsh \\
\hline Weight (g) & $5.1 \pm 0.5$ & $1.6 \pm 0.1$ & $0.3 \pm$ \\
\hline Height $(\mathrm{cm})$ & $158.2 \pm 5.4$ & $96.9 \pm 4.0$ & $50.2 \pm 4.2$ \\
\hline $\begin{array}{l}\text { Density } \\
\left(\text { no. } \mathrm{m}^{-2} \text { ) }\right.\end{array}$ & $120.4 \pm 9.7$ & $154.4 \pm 7.6$ & $1068.6 \pm 101.6$ \\
\hline
\end{tabular}

the Midmarsh site appeared to have more standing water. This may be due to the fact that the Midmarsh site is lower than the Creekside levees and also lower than the Highmarsh. Thus it is possible that stagnant conditions (standing water) resulted in low aerial biomass and in turn low NAPP for Midmarsh. Two types of hypotheses based on genetic and environmental variation have been proposed to explain the observed differences in these parameters. Electrophoretic studies by Shea et al. (1975) and transplant studies by Valiela et al. (1978) have failed to show genetic differences between plants from different zones. Wiegert et al. (1983) proposed that stagnant water reduces iron availability and increases free hydrogen sulfide. The latter accumulates in stagnant conditions and may reduce nitrogen uptake by the plants. Anoxia may also influence root function.

Similar seasonal cycles in abundance of aboveground live and dead biomass were observed each year at each site. The quantity of live material reached a maximum in late summer and early fall. Although the relative biomass was larger, the same seasonal pattern was observed at Sapelo Island, Georgia (Schubauer \& Hopkinson 1984). The abundance of dead material (Fig. 3) reached a maximum in winter and was about 6 mo out of phase with respect to live material. The variations in abundance of dead material in North Inlet exhibited a much more defined seasonal pattern than Sapelo Island. This pattern may be the result of colder winters at the more northern location causing more complete die-back in aboveground vegetation.

The Creekside site showed a large amount of variation in live biomass from summer to summer with 1983 and 1984 biomass being significantly higher than 1981, 1982 and 1985. The variation in aboveground biomass at Creekside and possibly Midmarsh may be attributable to changes in the environment. Numerous studies (Adams 1963, Haines \& Dunn 1976, Mendelssohn \& Marcellus 1976, Zedler et al. 1980, Linthurst \& Blum 1981, Linthurst \& Seneca 1981) have shown that aerial growth rates in Spartina alterniflora are reduced 
as salinity increases. At high salinities, it is thought that more energy is expended by the plants on metabolic regulation and internal ion balance than on growth process (Haines \& Dunn 1976). However, Longstreth \& Strain (1977) concluded from laboratory studies that the effects of salinity stress in $S$. alterniflora growth can be offset by increased illumination.

Aerial growth of Creekside Spartina alterniflora increased rapidly during the first half of 1983 and 1984
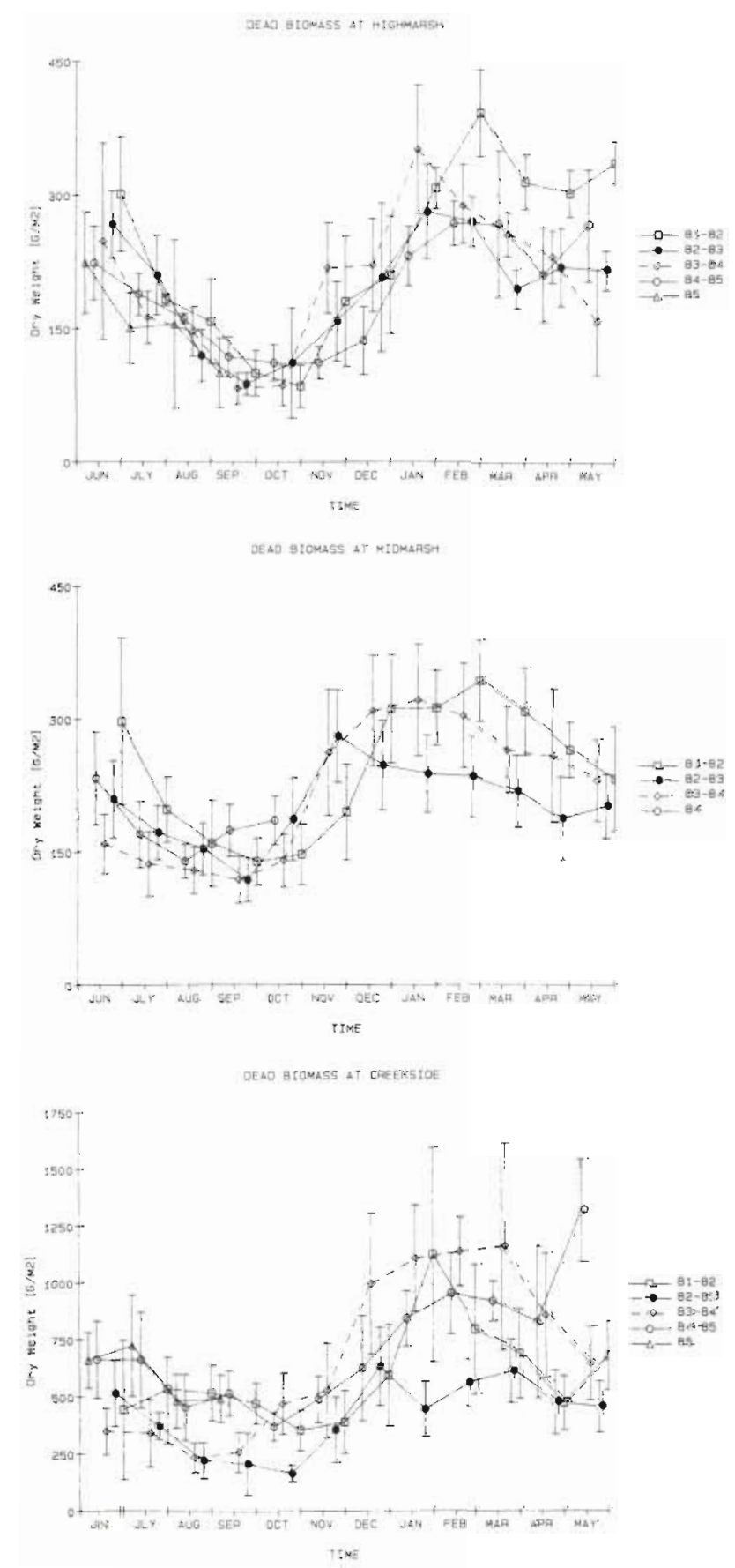

Fig. 3. Monthly aboveground dead biomass at Highmarsh, Midmarsh and Creekside sites. Vertical bars: $95 \% \mathrm{CI}$
(Fig. 2). Monthly measurements of salinity and the amount of rainfall in the North Inlet area during the study period are given in Fig. 4. From these data, it is suggested that there was much more rain and thus lower salinities in North Inlet during the late winter and spring (January to May) of 1983 and 1984. The coincidence of the periods of reduced salinity with that of high growth in Creekside $S$. alterniflora suggests that elevated amounts of rainfall and concurrent reduction in salinities due to upland runoff and rainfall may lead to changes in primary productivity. Adams (1963) noted that rainfall decreased soil salinity for varying periods of time in North Carolina marshes. Although rain fell over the entire marsh, the Creekside area has higher infiltration into its sediments (Wiegert et al. 1983) and is also covered by the tides a greater proportion of the time. This site might therefore be more likely to show a response to reduced salinities than the corresponding Highmarsh or Midmarsh sites. A concurrent study (Wolaver pers. comm.) of soil salinity profiles indicated lower salinities in the Creekside marsh soils at this time.

Monthly decomposition rates of aerial biomass are shown in Fig. 5. Month-to-month variations in the rate of biomass disappearance from the mesh bags varied from not detectable to $35 \%$. A seasonal variation in the rates was also observed; the summer decomposition proceeding faster than that of the winter. These rates are comparable to those reported by Kirby \& Gosselink (1976) in Lousiana, Kruczynski et al. (1978) in Florida, and Odum \& De La Cruz (1967) in Georgia Spartina alterniflora marshes. Unlike Marinucci (1982), who concluded that rates of decomposition were higher with increasing tidal inundation, we found increasing decomposition rates from Creekside to Highmarsh. McKee \& Seneca (1982) observed a similar occurrence in several North Carolina marshes and attributed lower rates of decay in Creekside plants to greater amounts of stem tissue.

The monthly measurements of NAPP were summed to yield yearly values (Table 2 ). In the harvest method, NAPP integrates accumulated biomass over long periods of time. Mean NAPP was highest at Creekside (2069 $\left.\mathrm{g} \mathrm{m}^{-2} \mathrm{yI}^{-1}\right)$, then Highmarsh $\left(1113 \mathrm{~g} \mathrm{~m}^{-2} \mathrm{yr}^{-1}\right.$ ) and finally lowest at Midmarsh $\left(649 \mathrm{~g} \mathrm{~m}^{-2} \mathrm{yr}^{-1}\right)$. Yearto-year NAPP varied about $25 \%$ for Creekside, $12 \%$ for Midmarsh and $3 \%$ for Highmarsh, i.e. within our $20 \%$ variability limits for sampling live biomass.

The validity of comparing NAPP values in salt marshes is confounded by the lack of a universally accepted technique and suitable intercalibration experiments. Shew et al. (1981) related their method to a number of previously reported methods by comparing calculated turnover rates with turnover rates determined from longevity experiments (Table 3). Because 
NAPP was also known for the various studies, the turnover data also implied under- or overestimates of NAPP. In general, the peak standing crop methods of Milner \& Hughes (1968) and Smalley (1959) lead to underestimates, while the methods of Wiegert \& Evans (1964) and Lomnicki et al. (1968) lead to overestimates. The modified Lomnicki et al. (1968) or Shew et al. (1981) method utilized in this study is thought to be a slight overestimate. Within the limits of the data, it appears that the Highmarsh NAPP $\left(1284 \mathrm{~g} \mathrm{~m}^{-2} \mathrm{yr}^{-1}\right)$ for North Inlet is a higher NAPP than that determined by Shew et al. (1981) for a North Carolina highmarsh (454 $\mathrm{g} \mathrm{m}^{-2} \mathrm{yr}^{-1}$ ). In contrast, estimates of NAPP for North Inlet Creekside $\left(2031 \mathrm{~g} \mathrm{~m}^{-2} \mathrm{yr}^{-1}\right)$ and Highmarsh (1284 $\left.\mathrm{g} \mathrm{m}^{-2} \mathrm{yr}^{-1}\right)$ are lower than those reported for Sapelo Island, Georgia (3700 and $1538 \mathrm{~g} \mathrm{~m}^{-2} \mathrm{yr}^{-1}$, respectively) by Gallagher et al. (1980) utilizing a modified Wiegert \& Evans (1964) method.

Unlike aboveground live biomass, belowground live biomass in North Inlet was greatest at the Highmarsh site, ranging from 2500 to $5000 \mathrm{~g} \mathrm{~m}^{-2}$ (Fig. 6). Live material varied from 1500 to $3300 \mathrm{~g} \mathrm{~m}^{-2}$ at the Creekside site (Fig. 6).

The amount of live material belowground in North Inlet was less than that observed in Georgia (Schubauer \& Hopkinson 1984) and Massachusetts (Valiela et al. 1976). Seasonal cycles in the abundance of live and dead belowground material were also observed in North Inlet. The amount of live material reached a maximum in the fall. The amount of below-
Table 2. Spartina alterniflora. Net aerial primary production ( $\mathrm{g} \mathrm{m}^{-2} \mathrm{yr}^{-1}$ ) for the different zones in the North Inlet marsh

\begin{tabular}{|cccc|}
\hline Time & Creekside & Midmarsh & Highmarsh \\
\hline Jun 81-May 82 & 1755 & 778 & 1313 \\
Jun 82-May 83 & 2350 & 817 & 1301 \\
Jun 83-May 84 & 2460 & 729 & 1272 \\
Jun 84-May 85 & 1602 & & 1250 \\
\hline
\end{tabular}

Table 3. Spartina alterniflora. Turnover or P/B rates (times $\mathrm{yr}^{-1}$ ) for aboveground and belowground marsh. Aboveground values are means for $3 \mathrm{yr}$; all ratios computed with peak live and peak dead values

\begin{tabular}{|c|c|c|c|c|c|c|}
\hline & \multicolumn{2}{|c|}{ Creekside } & \multicolumn{2}{|c|}{ Midmarsh } & \multicolumn{2}{|c|}{ Highmarsh } \\
\hline & Live & Dead & Live & Dead & Live & Dead \\
\hline Aboveground & 2.1 & 2.2 & 2.3 & 2.1 & 5.1 & 3.2 \\
\hline Belowground & 0.7 & 1.1 & - & - & 1.1 & 1.4 \\
\hline
\end{tabular}

ground dead material reached a maximum in winter and spring at the Creekside site and in summer at the Highmarsh site. The greatest maximum in live biomass occurred at similar times above and belowground at both Creekside and Highmarsh. These results contrast with those of Schubauer \& Hopkinson (1984) who found a temporal asynchrony between belowground and aboveground biomass abundance in Georgia

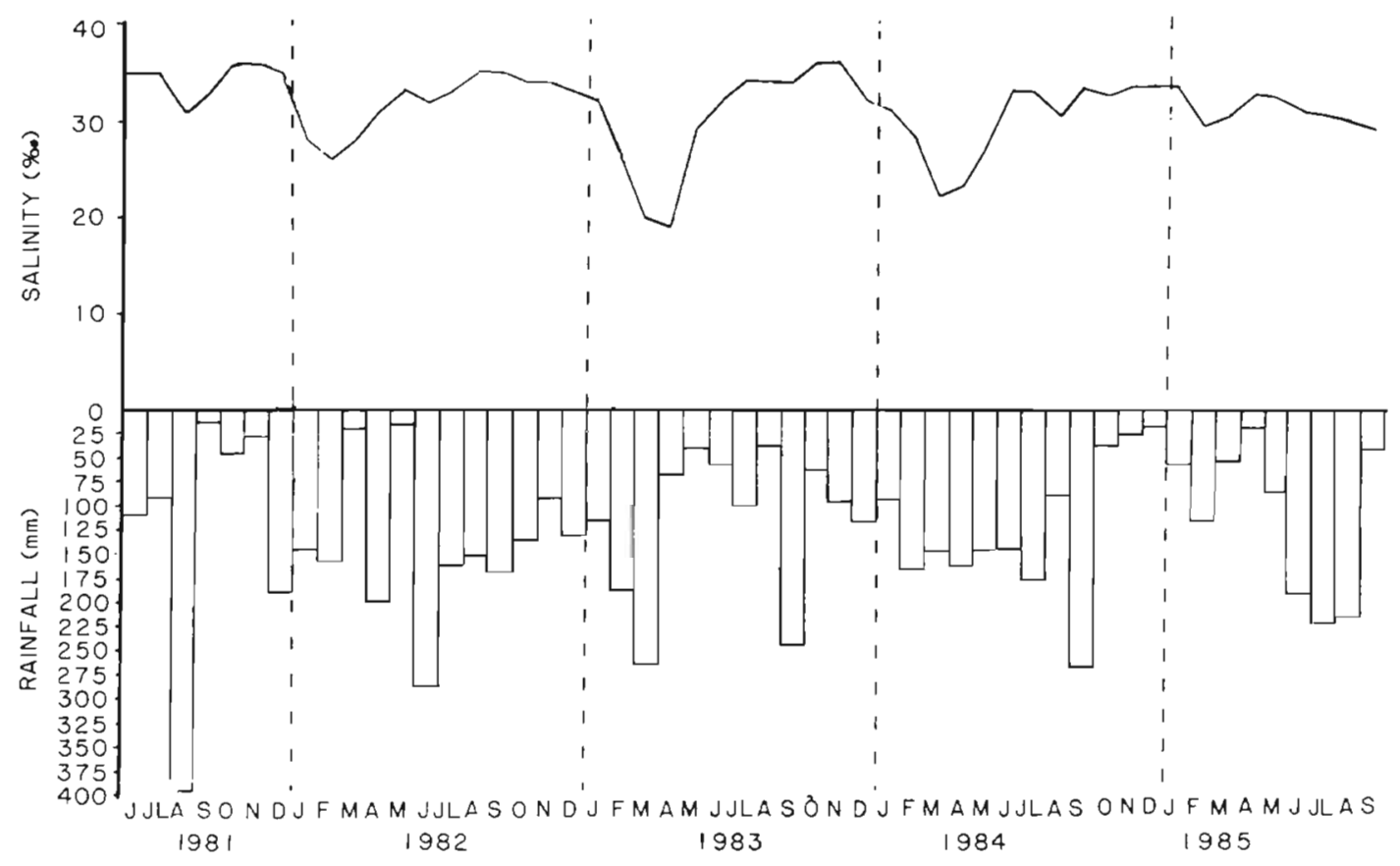

Fig. 4. Monthly accumulated rainfall from Hobcaw Plantation near Georgetown, South Carolina, and mean monthly salinities of daily water samples taken at Clambank in North Inlet (Fig. 1) 

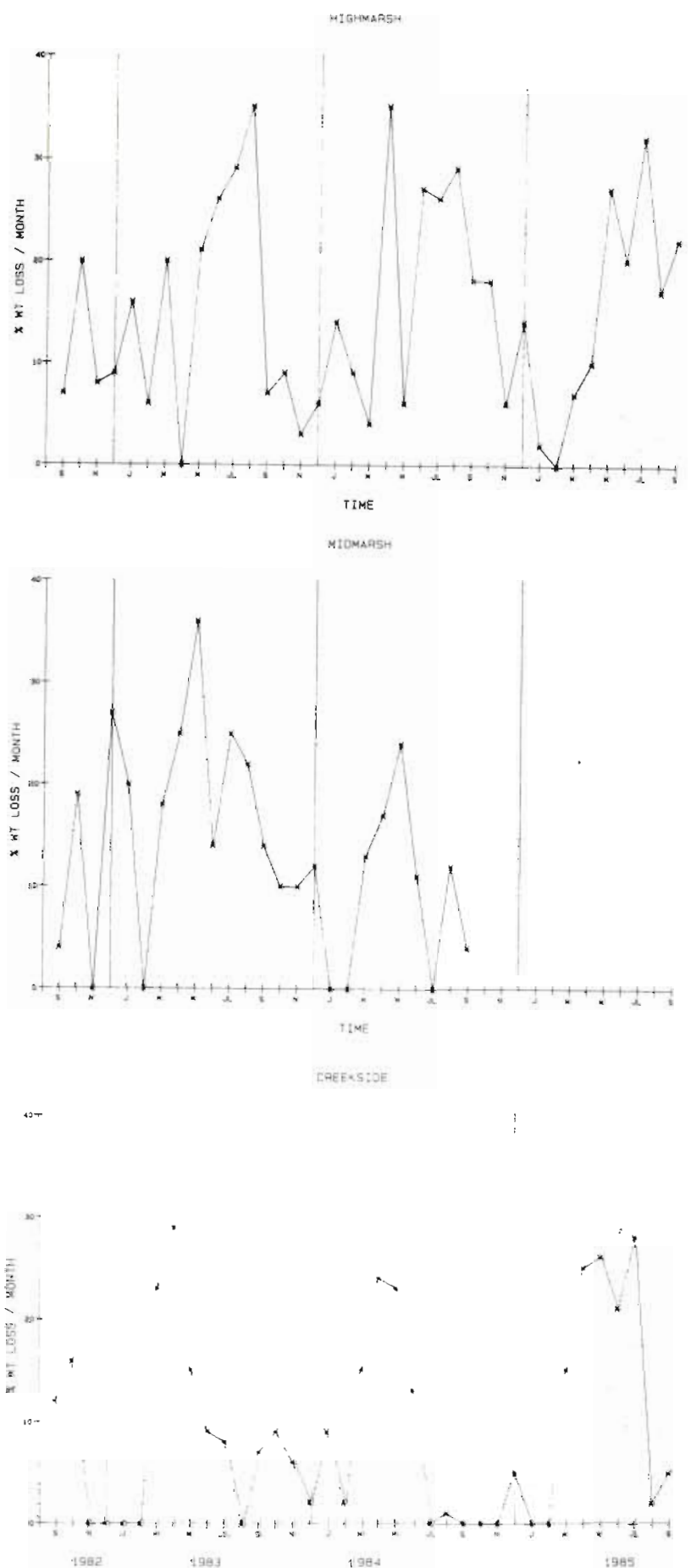

Fig. 5. Aboveground decomposition rates of macrodetritus in North Inlet

marshes. They interpreted their data to mean aboveground organic material was being stored belowground in winter and then utilized for growth in spring.

Net belowground primary production (NBPP) of Spartina alterniflora in North Inlet ranged from 2,363 g $\mathrm{m}^{-2} \mathrm{yr}^{-1}$ at Creekside to $5445 \mathrm{~g} \mathrm{~m}^{-2} \mathrm{yr}^{-1}$ at High-
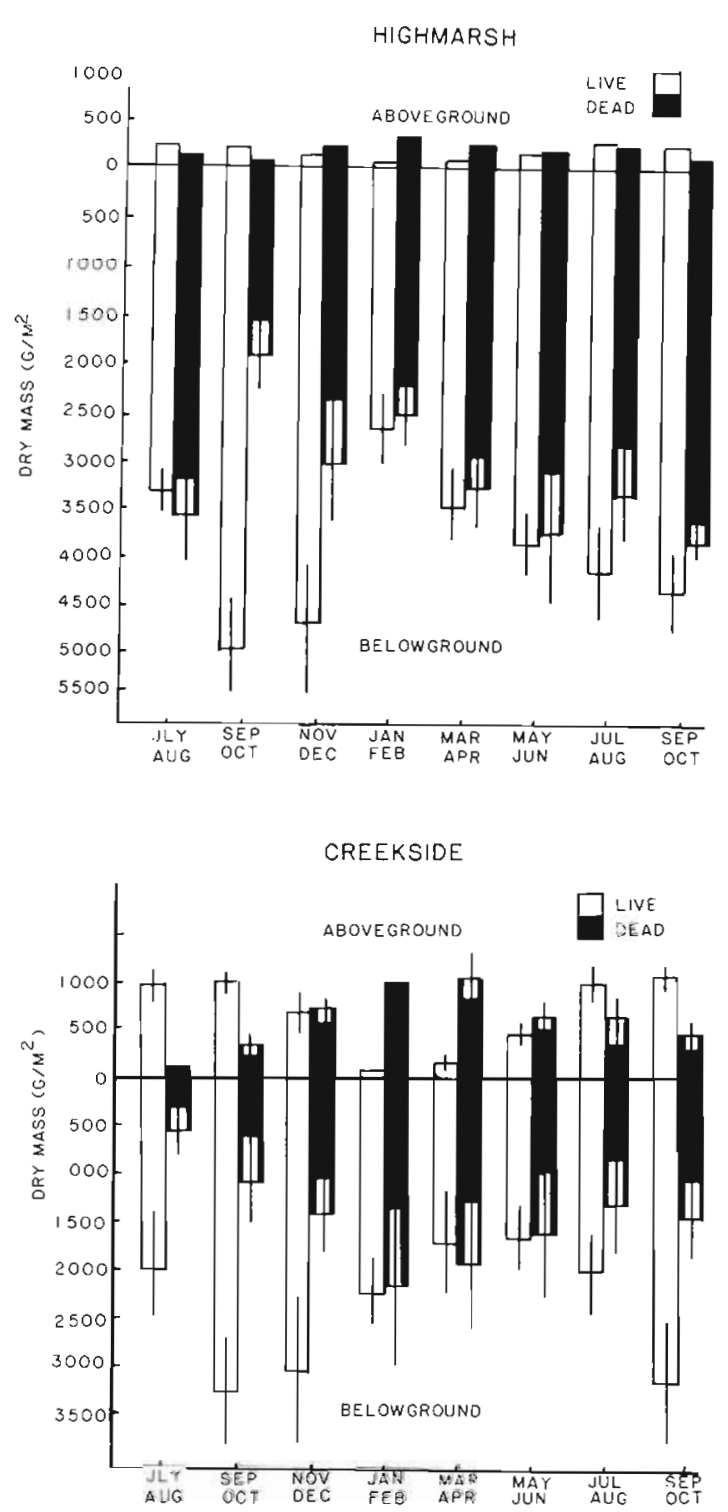

Fig. 6. Above- and belowground live and dead biomass with $95 \%$ CI for Highmarsh and Creekside, 1983-1984

marsh site and are among the highest values reported (Table 4). However, our observed NBPP of S. alterniflora in North Inlet was below the theoretical limits of belowground production $\left(6500 \mathrm{~g} \mathrm{C} \mathrm{m}^{-2} \mathrm{yr}^{-1}\right)$ for Sapelo Island, Georgia, as estimated by Morris et al. (1984). We utilized the Smalley (1959) method to calculate NBPP; it is thought to be a slight underestimate of net primary production because this method, although advocated by Schubauer \& Hopkinson (1984), does not take into account loss of biomass by decomposition.

Total net primary production for Spartina alterniflora in 1983-1984 varied from $4833 \mathrm{~g} \mathrm{~m}^{-2} \mathrm{yr}^{-1}$ at Creekside to $6717 \mathrm{~g} \mathrm{~m}^{-2} \mathrm{yr}^{-1}$ at Highmarsh. These values are similar to the previously reported high of $7620 \mathrm{~g}$ $\mathrm{m}^{-2} \mathrm{yr}^{-1}$ for medium $S$. alterniflora in Georgia 
(Schubauer \& Hopkinson 1984). The method we used to estimate NAPP is generally thought to give lower values than the preceeding authors', although we utilized essentially the same NBPP methods.

Turnover rates offer estimates of how fast a given component is being replaced within a system, providing information on the dynamic aspects of that component. The turnover rates (NAPP/maximum biomass) of aboveground live Spartina alterniflora in North Inlet ranged from 2.1 times $\mathrm{yr}^{-1}$ at Creekside and Midmarsh to 5.1 times $\mathrm{yr}^{-1}$ in Highmarsh (Table 3). Year-to-year variation within a given site was 21 to $30 \%$. The North Inlet turnover rates encompass those reported by Hopkinson et al. (1978) of 3.5 times $\mathrm{YT}^{-1}$ in Louisiana and are higher than those of Shew et al. (1981) of 1.9 times $\mathrm{yr}^{-1}$ for a Highmarsh in North Carolina. The turnover rates for dead aerial material were similar, ranging from 2.1 to 3.2 times $\mathrm{yr}^{-1}$. Belowground turnover rates for live material range from 0.7 times $\mathrm{yr}^{-1}$ for Creekside to 1.1 times $\mathrm{yr}^{-1}$ for Highmarsh. Dead belowground material turnover rates were 1.1 and 1.4 times $\mathrm{yr}^{-1}$ respectively. In contrast to North Inlet, turnover rates for dead marsh materials in Georgia (Schubauer \& Hopkinson 1984) and Massachusetts (Valiela et al. 1976) were always lower than those for live materials.

The magnitudes of the ratio of live belowground to aboveground material (root-to-shoot ratio) are thought to be reflections on the stressfulness of the environment on plants (Valiela et al. 1976). High values of this ratio indicate more stress. These ratios vary seasonally in North Inlet from near 2 in summer to 32 in winter (mean 18.3) for Creekside plants. Highmarsh plants had even higher ratios ranging from 6 to 76 (mean 35.2). Summer values for Creekside compare favorably with that of 1.7 found by Schubauer \& Hopkinson (1984) for a Sapelo Island, Georgia salt marsh. The ratio of below to aboveground net primary production was 1.0 for Creekside and 4.3 for Highmarsh.

In environments made harsh by the presence of anoxia, nutrient scarcity, and high salinity, etc., reduced water and nutrient uptake per unit root may be overcome by a greater investment of biomass in roots (Hopkinson \& Schubauer 1984). In North Inlet, the higher root-to-shoot ratios for Spartina alterniflora than in other areas, notably Georgia, may be the result of the higher average salinities this estuarine system normally experiences.

The conversion of solar energy via photosynthesis into Spartina biomass available to heterotrophs is an important aspect in the dynamics of the salt marsh system. For North Inlet, the rate of light incidence for 1982-1983, a rainy year, was $125675 \mathrm{ly} \mathrm{yr}^{-1}(1.26 \times$ $102 \mathrm{kcal} \mathrm{cm}^{-2} \mathrm{yr}^{-1}$ ). Utilizing values of 3.2 and $2.6 \mathrm{kcal}$ $\mathrm{g}^{-1}$ the solar conversion efficiencies at Creekside $(0.55 \%)$ and Highmarsh $(0.28 \%)$ were calculated (Nixon \& Oviatt 1973). When belowground net primary production is included, the solar conversion efficiencies are $2.3 \%$ for Creekside and $2.2 \%$ for Highmarsh. Tumer (1976) found that the efficiency of solar conversion for aboveground Spartina was 0.20 and $0.35 \%$, with slightly lower values for Highmarsh than for Creekside. On a global scale, Odum (1983) reports an average solar conversion efficiency of $0.1 \%$ and a maximum of $4.0 \%$.

The spatial heterogeneity of plants in the salt marsh is closely associated with the sediment they live in and the varying influence of tidal inundation. The spatial differences in primary production may be continuous (Wiegert et al. 1983), but for conceptual reasons the marsh is usually divided into specific areas or zones. In North Inlet Highmarsh, numerous small aerial shoots and a large belowground biomass combine for high net

Table 4. Spartina alterniflora. Comparison of aboveground and belowground productivity $\left(\mathrm{g} \mathrm{m}^{-2} \mathrm{yr}^{-1}\right)$ according to location and height form

\begin{tabular}{|llccll}
\hline Area & Height form & \multicolumn{3}{c}{ Net primary production } & Source \\
& & Above & Below & Total & \\
\hline \multirow{2}{*}{ Nova Scotia } & NR & 803 & 1051 & 1851 & Livingstone \& Patriquin 1981 \\
Massachusetts & NR & 420 & 3500 & 3920 & Valiela et al. 1976 \\
New Jersey & Short & 500 & 2300 & 2800 & Smith et al. 1979 \\
North Carolina & Short & 650 & 460 & 1110 & Stroud 1976, Stroud \& Cooper 1968 \\
& Tall & 1300 & 500 & 1800 & Stroud 1976, Stroud \& Cooper 1968 \\
South Carolina & Short & 1272 & 5445 & 6717 & This study \\
& Medium & 775 & - & - & This study \\
& Tall & 2460 & 2363 & 4833 & This study \\
& Short & 1350 & 2020 & 3370 & Gallagher \& Plumley 1979 \\
& Medium & 2840 & 4780 & 7620 & Schubauer \& Hopkinson 1984 \\
& Tall & 3700 & 2110 & 5810 & Gallagher \& Plumley 1979 \\
NR: Not reported; & Short = Highmarsh; Medium $=$ Midmarsh; Tall = Creekside & \\
\hline
\end{tabular}


primary production. Creekside marsh is typified by large less numerous plants with an equivalent belowground biomass which also yields high net primary production. Midmarsh with weak sparse plants in a water-logged environment has lower NAPP. Thus, Spartina alterniflora can be a successful primary producer in a broad range of environments.

It has long been known that Spartina exhibited seasonal cycles in growth and mortality both above and belowground. These seasonal cycles seem to be a response to temperature and light. The inter-annual variations in Creekside $S$. alterniflora biomass in North Inlet are thought to be the first report of such a temporal event. In North Inlet estuary, this inter-annual variation in biomass seems to be correlated with rainfall and the concurrent depression of salinity. The implications of grass biomass varying in wet years compared to dry years is striking. Most modeling efforts on marshes have assumed a constancy of plant biomass and productivity which must now be reexamined in view of the present findings. Finally, the amount of plant biomass available to the system for processing and exchange varies from year to year depending on environmental conditions. This variability may induce other changes in the system, particularly in the detritus food chain, which are not immediately obvious during a particularly wet or dry year.

Acknowledgements. The authors are grateful to the numerous students, staff, and faculty of the Baruch Institute for their assistance in the field sampling. We also thank Dr. C. S. Hopkinson who reviewed an early draft of the manuscript. David Stilwell and Carol Schmidt were invaluable in the initial organization and development of the project. Tom Williams shared his rainfall data and engaged us in helpful discussions. This work was part of the Long Term Ecological Research (LTER) project in the North Inlet supported by NSF grant BSR-8012165. This publication is No. 615 of the Belle W. Baruch Institute for Marine Biology and Coastal Research.

\section{LITERATURE CITED}

Adams, D. A. (1963). Factors influencing vascular plant zonation in North Carolina salt marshes. Ecology 44: 445-456

Gallagher, J., \& Plumley, F. (1979). Underground biomass profiles and productivity in Atlantic coastal marshes. Am. J. Bot. 66: 156-161

Gallagher, J., Reimold, R., Linthurst, R. A., Pfeiffer, W. J (1980). Aerial production, mortality and mineral accumulation-export dynamics in Spartina alterniflora and Juncus roemerianus plant stands in a Georgia salt marsh. Ecology 61: 303-312

Haines, B. L., Dunn, E. L. (1976). Growth and resource allocation responses of Spartina alterniflora Loisel. to three levels of $\mathrm{NH}_{4}^{+}-\mathrm{N}, \mathrm{Fe}$, and $\mathrm{NaCl}$ in solution culture. Bot Gaz. 137: 224-230

Hopkinson, C. S., Schubauer, J. P. (1984). Static and dynamic aspects of nitrogen cycling in the salt marsh graminoid. Spartina alterniflora Loisel. Ecology 65: 961-969

Hopkinson, C. S., Gosselink, J. G., Parrando, R. T (1978).
Aboveground production of some marsh plants species in Coastal Louisiana. Ecology 59: 760-769

Keefe, W. (1972). Marsh production: a summary of the literature. Contr mar Sci. 16: 163-181

Kirby, C. J., Gosselink, J. G. (1976). Prumary production in a Louisiana Gulf Coast Spartina alterniflora salt marsh. Ecology 57: 1052-1059

Kjerfve, B., Greer, J., Crout, R. (1978). Low-frequency response of estuarine sea level to non-local forcing. In: Wiley, M. (ed.) Estuarine interactions. Academic Press, New York, p. 497-514

Kjerfve, B., Proehl, J., Schwing, F., Seim, H., Marozas, M. (1982). Temporal and spatial considerations in measuring estuarine water fluxes. In: Kennedy, V. (ed.) Estuarine comparisons. Academic Press, New York, p. 37-51

Kruczynski, W. L., Subrahmanyam, C. B., Drake, S. H. (1978) Studies on the plant community of a north Florida USA salt marsh. I. Primary production. Bull. mar. Sci. 28 $707-715$

Linthurst, R. A., Blum, A. (1981). Growth modifications of Spartina alterniflora Loisel. by the interaction of $\mathrm{pH}$ and salinity under controlled conditions. J. exp. mar Biol. Ecol. 55: 207-208

Linthurst, R. A., Seneca, E. D. (1981). Aeration, nitrogen and salinity as determinants of Spartina alterniflora Loisel. growth response. Estuaries 4: 53-63

Livingstone, D. C., Patriquin, D. G. (1981). Belowground growth of Spartina alterniflora Loisel: Habit, functional biomass and non-structural carbohydrates. Estuar. coast. Shelf Sci. 12: $579-588$

Lomnicki, A., Bandola, E., Jankowska, K. (1968). Modification of the Wiegert-Evans method for estimation of net primary production. Ecology 49: 147-149

Longstreth, D. J., Strain, B. R. (1977). Effects of salinity and illumination on photosynthesis and water balance of Spartina alterniflora Loisel. Oecologia (Berl.) 31: 191-199

Marinucci, A. C. (1982). Trophic importance of Spartina alterniflora production and decomposition to the marsh estuarine ecosystem. Biol. Conserv. 22: 35-58

McKee, K. L., Seneca, E. D. (1982). The influence of morphology in determining the decomposition of two salt marsh macrophytes. Estuaries 5: 302-309

Mendelssohn, I. A., Marcellus, K. L. (1976). Angiosperm production of three Virginia marshes in various salinity and soil nutrient regimes. Chesapeake Sci. 17: 15-23

Milner, C., Hughes, R. E. (1968). Methods for the measurement of primary production of grasslands. IBP Handbook No. 6, Blackwell Scientific Publ., Oxford

Morris, J. T., Houghton, R. A., Botkin, D. B. (1984). Theoretical limits of belowground production by Spartina alterniflora: an analysis through modelling. Ecol. Modelling 26: $155-175$

Nixon, S., Oviatt, C. (1973). Ecology of a New England salt marsh. Ecol. Monogr 43: 463-498

Odum, E. P. (1983). Basic ecology. Saunders College Publishing, New York

Odum, E. P., De La Cruz, A. A. (1967). Particulate organic detritus in a Georgia salt marsh-estuarine ecosystem. In: Lauff, G. H. (ed.) Estuaries. American Association for the Advancement of Science, Washington, D.C., p. 383-388

Schubauer, J. P., Hopkinson, C. S. (1984). Above and belowground emergent macrophyte production and turnover in a coastal marsh ecosystem, Georgia. Limnol. Oceanogr 29: 1052-1065

Shea, M. L., Warren, R. S., Niering, W. A. (1975). Biochemical and transplantation studies of the growth form of Spartina 
alterniflora on Connecticut salt marshes. Ecology 56 461-466

Shew, D. M., Linthurst, R. A., Seneca, E. D. (1981). Comparison of production computation methods in a southeastern North Carolina Spartina alterniflora salt marsh. Estuaries 4: $97-109$

Smalley, A. E. (1959). The role of two invertebrate populations, Littorina irrorata and Orchelimum fidicinium, in the energy flow of a salt marsh ecosystem. Ph. D. thesis, Univ. of Georgia, Athens

Smith, K., Good, R. E., Good, N. F. (1979). Production dynamics for above- and belowground components of a New Jersey Spartina alterniflora tidal marsh. Estuar. coast. Shelf Sci. 9: 189-201

Stroud, C. M. (1976). Net primary production of belowground material and carbohydrate patterns in two height forms of Spartina alterniflora in two North Carolina marshes. Ph. D. thesis, North Carolina State Univ., Raleigh

Stroud, C. M., Cooper, A. W. (1968). Color infrared aerial photographic interpretation and net primary productivity of a regularly flooded North Carolina marsh. North Carolina Water Resources Institute, Raleigh, N. Carolina, Report 14, p. 1-86
Turner, R. E. (1976). Geographic variations in salt marsh macrophyte production: a review. Contr. mar Sci. 20: $47-68$

Valiela, J., Teal, J., Deuser, W. (1978). The nature of growth forms in the salt marsh grass Spartina alterniflora. Am. Nat. 112: 461-470

Valiela, J., Teal, J., Persson, N. (1976). Production and dynamics of experimentally enriched salt marsh vegetation. Belowground biomass, Limnol. Oceanogr. 21 : 245-252

Wiegert, R. G., Evans, F. C. (1964). Primary production and the disappearance of dead vegetation in an old field in southeastern Michigan. Ecology 45: 49-63

Wiegert, R. G., Chalmers, A. G., Randerson, P. F. (1983). Productivity gradients in salt marshes: the response of Spartina alterniflora to experimentally manipulated soil water movement. Oikos 41:1-6

Zedler, J. B., Winfield, T., Williams, P. (1980). Salt marsh productivity with natural and altered tidal circulation. Oecologia (Berl.) 44: 236-240 